\title{
MINERAL RESOURCES OF CONTINENTAL EUROPE
}

\author{
By Dr. W. J. Arkell
}

W HAT exactly are the mineral resources of the German Old Reich, and what does she stand to gain from the resources of her allies and her conquests? What attractions are offered by the remaining neutral countries of Europe? What minerals deficient in Europe can be supplied by the U.S.S.R. ? There appears to be no up-to-date account of this important subject in the English language.

In the following synopsis Continental Europe is understood to mean Europe less the British Isles, Spitsbergen, Turkey and Russia.

Only minerals of strategic importance are dealt with. They may be grouped as follows :

(1) Fuels : oil and coal.

(2) Major metals : iron, copper, lead, zinc, tin.

(3) Steel alloy metals : manganese, chromium, nickel, cobalt, tungsten, molybdenum, vanadium, zirconium, titanium.

(4) Other metals: aluminium, magnesium, mercury, antimony, arsenic, uranium, platinum.

(5) Fertilizers: phosphates and potash; also pyrites, needed for the manufacture of superphosphate.

(6) Other important non-metals, used in the electrical, metallurgical and other industries (mica, graphite, asbestos, fluorspar, talc, diamond).

\section{Germany : Old Reich}

Oil. Germany's maximum potential production of crude oil is probably much less than one million tons a year, or only about 12 per cent of the European production and less than 17 per cent of her peace-time needs. But her abundant coal supplies enable her to augment her natural supplies with at least $2 \frac{1}{2}$ million tons of synthetic oil, and theoretically there is no reason why synthetic plants should not be multiplied until Germany produces all the oil she wants. The process is, however, very extravagant and would be pointless so long as imports were assured, and in war-time the synthetic plants are highly vulnerable to air attack.

Coal. Germany possesses abundant coal. She has more than half the total European reserves of both hard coals and lignite, and at present she produces 82 per cent of the total European output of lignite, which is 36 per cent of the world's total production, although Europe has only 2 per cent of the world's reserves.

Iron. Germany possessed 17 per cent of the European reserves of metallic iron, but her ores are mainly low-grade and therefore extravagant to work. For her immense steel industry she was mainly dependent on imports.

Copper. In the Mansfeld stratified deposit Germany possesses the most important copper occurrence in Central Europe, and with more than 20 per cent she had the highest copper production of any European country after Yugoslavia. But the total European production being only 6.3 per cent of the world production and the reserves (including huge deposits in Spain) only 10 per cent of world reserves, the total amount of copper is inadequate for the highly developed electrical industry. It is being increased by developing newly discovered low-grade ores in Silesia and eastern Hessen. The latter field is said to be perhaps as important as Mansfeld itself.

Zinc and Lead. In her share of Upper Silesia, Germany possessed about 15 per cent of the richest zinc and lead deposits in Europe, the rest belonging to Poland. These and numerous other deposits in different parts of the country gave Germany reserves of about $\mathbf{7 \cdot 4}$ million tons of recoverable zinc and 1.8 million tons of recoverable lead. With 37 per cent and 29 per cent she heads the European production of both zinc and lead. But whereas the zinc production is fairly adequate, the lead production and reserves of Germany and all European countries are inade. quate (only 15.8 per cent of world production).

Tin. Germany produced 5.4 per cent of the very small European tin output, which altogether is only 0.58 per cent of the world's production There is no hope of substantially increasing this amount, which is totally inadequate.

Manganese. Deposits of high-grade ores such as are normally used for the extraction of man. ganese are negligible in Germany. But there are vast reserves (at least 250 million tons of manganiferous iron ore, from which good quality ferro-manganese is made. From these ores Germany in 1936 produced 47 per cent of her owr requirements of metallic manganese (in a norma year about 400,000 tons are consumed). 
Nickel. Although recent production of nickel ore in Germany has been very small (268 tons was the greatest amount in any year from 1935 to 1938), there are a number of deposits, and production can be increased about four-hundred-fold in times of stress. The output reached 102,000 tons in 1917. This represents about 2,050 tons of nickel, or 73 per cent of the total maximum annual European production for the years 1935-37, and 30 per cent of Germany's imports of nickel in the normal peace-time year 1936.

Molybdenum. About 40-50 tons of molybdenum a year can be produced as a by-product from the Mansfeld copper ores, but this is not 8 per cent of the European production, which in turn is only about 4 per cent of world production.

Vanadium. Germany's normal consumption of about 250 tons of vanadium is capable of being met by concentration of small traces which occur in the iron ores from Baden, Lorraine and Sweden, smelted in Germany.

Tungsten, Cobalt and Titanium are virtually absent.

Aluminium. Production of aluminium from Germany's negligible deposits of bauxite, if extended to the maximum, could scarcely amount to 2 per cent of her imports in recent years. On the other hand, the Germans have brought to a high state of efficiency processes for the production of aluminium from clays, kaolins and low-grade ores.

Magnesium. In Silesia there are small but pure deposits of magnesite, and the carnallite of the Stassfurt salt deposits yields $5 \cdot 5$ per cent of magnesium and has been extensively used as a raw material. Statistics are not available.

Mercury. Recent intensive exploitation of home supplies of cinnabar are believed to produce $200-300$ tons of mercury a year, or about 30 per cent of the recent average German consumption. (This would represent about 6 per cent of the total European production and about 5 per cent of world production.)

Antimony. Germany has produced as much as 700 tons of metallic antimony in a year, which is equal to about 20 per cent of her consumption in recent years.

Arsenic. There are extensive deposits in Silesia, and as much as 4,600 tons of white arsenic have been produced in a year (1930), and as much as 2,800 tons have been exported recently in a year (1938).

Phosphates. Like many countries, Germany has various low-grade phosphatic rocks which can be drawn upon in time of war, but are scarcely worth working in peace-time. Also she has enormous reserves of phosphatic iron ores which, when smelted by the Thomas process, yield good basic slag. But of true high-grade phosphate deposits she has scarcely any.

Pyrites. Germany has twice as much pyrites as any other European country except Spain. The reserves amount to about 100 million tons, or 13 per cent of the known world reserves. In 1918 the production reached nearly 1 million tons a year, and it should be possible to exceed that now.

Sulphur. Nearly a quarter of a million tons of sulphur a year can be produced as a by-product of coal, coke and barytes industries, and during lead, zinc and copper mining. The actual amount produced hitherto in a year is probably more like half this figure.

Potash. Central Germany contains 80 per cent of Europe's deposits of potash, which are 96 per cent of the world's total reserves (less uncertain deposits in Russia). Her production in 1937 was 73 per cent of the European production and 62 per cent of world production.

Mica, Talc and Asbestos are almost entirely lacking in Germany; diamond does not occur in Europe.

Graphite. Germany leads European production. The deposits are extensive and easily accessible, and the output has reached 40,300 tons in a single year (1918). This would be 56 per cent of the European production if it had been repeated in 1937, and nearly 19 per cent of the world's total in recent years, as compared with 7 per cent in the British Empire and less than 4 per cent in the United States.

Fluorspar. In this Germany has a still more commanding position - a matter of importance in view of its great value in the steel industry. Her production is more than 68 per cent of the total European production and nearly 33 per cent of the world's total (as compared with $10 \cdot 7$ per cent in the British Empire).

\section{AUSTRIA}

Magnesium. The outstanding gain to the Reich war machine in taking over Austria was the acquisition of the world's largest and purest deposits of magnesite for the making of magnesium for incendiary bombs, flares and aircraft. For years Austria headed the world's production and has only recently been just outstripped by Russia.

Other metals. Minor assets are small quantities of iron, lead and antimony (more than double Germany's production of antimony has been reached). 
Talc. Austria's production of $16 \cdot 7$ per cent of the European total is four times as great as Germany's, and satisfies a need.

Graphite. Austria's graphite deposits are second only to Germany's. The two tcgether give Germany a commanding position with a production of more than 40,000 tons a year, or 74 per cent of the European production in 1937, and potentialities for producing more than 60,000 tons a year, as was done during the War of 1914-18 (28 per cent of the present-day world's total).

\section{Czechoslovakia}

Lignite. The Sudetenland contains a reserve of $11 \frac{1}{2}$ million tons of lignites of a quality far superior to those of Germany; they represent about 12 per cent of the European reserves.

Asbestos. With 15 per cent of the European production this will be a welcome asset, since Germany and Austria possess practically none.

Graphite. The graphite deposits of Bohemia and Moravia are among the most valuable in Europe, and production exceeded 41,000 tons in 1927equal to Germany's maximum production during the War of 1914-18. This extra acquisition gives Germany practically a monopoly of European graphite.

Uranium. Bohemia contains by far the most important uranium deposits in Europe, practically the only others being in Portugal. For many years she led the world's production.

Antimony. Czechoslovakia accounted for 30 per cent of Europe's antimony production in 1937.

\section{Poland}

Oil. Poland produced more than half a million tons of oil a year. The Germans and Russians took over the industry in full working order. The German share represented a production of only about 150,000 tons a year, but this is capable of substantial increase, and is a clear gain to Germany. It is considered probable that the oil from the Russian part of the field will also go to Germany.

Coal. The Dombrova and Ostrawa-Karwina coalfields made Poland the third largest coalproducing country in continental Europe, with 11 per cent of the output and 28 per cent of the reserves. She also has lignite reserves larger than those of Czechoslovakia and almost entirely undeveloped.

Zinc. Polish Upper Silesia contains a continuation of the German Silesian zinc and lead ores.
The output of zinc in 1937 was $15 \cdot 6$ per cent of the European production, and added to the German production it gives her more than 50 per cent of the total European production and about 12 per cent of world production. This is sufficient for German requirements of zinc in all circumstances.

\section{NORWAY}

The commodities that Norway can furnish are just those which Germany needed most, namely, the steel alloy metals and helpful quantities of copper and mica for the electrical industries.

Copper. The addition of the Norwegian copper production to the German represented an increase of 66 per cent, and the Norwegian output is capable of being stimulated.

Nickel. In 1917 Norway produced 78,000 tons of nickel ore, representing about 780 tons of metallic nickel, and there is no reason why this figure should not be exceeded under German direction if necessary.

Molybdenum. At present Norway is believed to be producing about 750 tons of molybdenite a year, representing about 450 tons of metallic molybdenum. It is the only important producing country in Europe.

Titanium. The Norwegian deposits of ilmenite and rutile are the largest in the world, and would suffice to furnish the world's supply of titanium for centuries. One quarter of the world's production came from Norway.

Chromium. In 1918 nearly 7,000 tons of chromite were produced. This is only a small amount, but it is valuable to Germany in the absence of other supplies.

Mica and Talc. In 1938 Norway produced more than 100 tons of sheet mica and probably at least 30,000 tons of talc. With Austria, this gives Germany 37 per cent of the European talc production and 27 per cent of the mica production.

\section{Luxemburg, Belgium, Holland, Denmark}

Iron. The only gain of real consequence accruing to Germany's mineral resources as the result of the invasion of these countries is the iron ore of Luxemburg. Although the production is only $7 \cdot 2$ per cent of the European total in terms of iron content, it is almost as great as Germany's own, and it is conveniently situated near the German western industrial districts and coal supplies. The amount produced in 1937 was nearly $2 \frac{1}{4}$ million tons of metallic iron. 


\section{FRANCE}

Iron. France has by far the largest reserves of iron in Europe, situated mainly in Lorraine. In terms of metallic iron they represent 47 per cent of the total European reserves, and the production in 1937 was 41.5 per cent of the European and 15.3 per cent of the world production.

Aluminium. The largest quantity of bauxite was also produced in France ( 32 per cent of European production) and the reserves are by far the largest in western Europe. In 1937 the production of bauxite in France was 18 per cent of the world's total, as compared with 10.7 per cent in the British Empire and 11.2 per cent in the United States.

Coal. France has the second largest coal production after Germany. The total production of Germany, France, Poland, Belgium and Holland represents practically 100 per cent of the European output, which is substantially greater than that of the British Empire, though the reserves of hard coal are only two-thirds as great as those of the Empire and the lignite reserves only one ninth as great.

Fertilizers. More than 70 per cent of the European production of phosphate rock came from France, and she holds about 36 per cent of the reserves. Alsace also contains the only considerable deposit of potash outside central Germany. The two together give Germany a monopoly with more than 90 per cent of the European reserves and production. and nearly 90 per cent of the whole world's potash reserve; though Russians have recently claimed to possess a still greater reserve.

Talc. France has the largest production of talc in Europe (31 per cent), and is the third largest producer in the world, after the United States and Manchuria. In 1937 and 1938 her exports alone substantially exceeded Germany's imports.

Fluorspar. Germany has a sufficiency of this mineral in her own territory, but the French production, although little more than a third as great as the German, is still in excess of that of the whole British Empire. Germany and France together produce about the same amount as the British Empire and United States combined.

\section{ITALY}

Italy lacks oil, coal, lignite, iron, copper, and most of the ferro-alloy metals. To this extent she is a heavy liability to the Central European war machine. For example, her civil consumption alone of oil and oil products was 3 million tons in 1938 and again in 1939, of which only 220,000 tons each year were supplied by Italy and Albania. This is not counting the heavy war consumption for her fleet, air force and mechanized columns in Africa. Therefore so soon as stocks are exhausted she will compete with Germany for Rumanian oil. The same applies to nearly all the indispensable metals.

There is, however, another side to the picture. Many of the other minerals are plentiful in Italy, and in at least two of them, mercury and sulphur, she easily heads the world's production. These and several of the other minerals produced by Italy happen to be scarce in Germany-especially bauxite, lead, and asbestos. In exchange for them Germany finds a market for some of her superabundance of coal and potash.

Sulphur. The Sicilian sulphur belt is by far the most important deposit of native sulphur in Europe, if not in the world. Italy accounts for 80 per cent of the European production.

Pyrites. Italy also has the third largest pyrites production in Europe.

Mercury. The cinnabar deposits of Idria (formerly in Austria) make Italy the world's leading producer of mercury. The only other largescale European deposits are in Spain.

Zinc and Lead. In 1937 Italy accounted for 16 per cent of the European zinc production and 13 per cent of the lead. The mines are mainly in Sardinia. Her average production over a number of years has been maintained at more than 77,000 tons of metallic zinc and more than 25,000 tons of metallic lead annually.

Manganese. Italy takes third place with 19 per cent of the European production of metallic manganese from high-grade ores, and it is believed that she is self-sufficient in this metal.

Aluminium. Italy also takes third place in the production of bauxite, with 18 per cent of the European total. Her reserves, however, are relatively small.

Antimony. Production is sporadic; but in 1937 Italy occupied third place with $\mathbf{1 4 \cdot 6}$ per cent of the European production.

Mica. In 1938 Italy occupied second place among European countries producing mica, the order being: Sweden with 129 tons, Italy with 120 tons, Norway with 102 tons, and Rumania with 22 tons.

Asbestos. Italy is a close second after Finland in the production of asbestos; but although she produces 39 per cent of the European total the amount is small, since Europe's production is only 3 per cent of the world's total. The Italian production is only equivalent to about a quarter of Germany's imports.

( $T_{0}$ be continued.) 